\title{
A Sex Chromatin Study of Chinese School Children
}

\author{
MING-TSO TSUANG* and HUEI-SHIANG TSUANG $\dagger$
}

The present study is an attempt to investigate the frequency of sex chromatin abnormality among Chinese children based on samples derived from school children and to compare the results with those reported by others. The main purpose of the study is to establish a base line against which to assess the frequency of sex chromatin abnormality among the Chinese psychiatric population, which will be reported subsequently (see Tsuang, 1972 for a preliminary report).

\section{Subjects}

In Taiwan, primary and secondary education is compulsory and universal. There are no special schools for mentally subnormal children. The enrolment of children into the schools irrespective of the intellectual performances is strictly enforced by the government. Therefore, the frequency of sex chromatin subnormality found in the schools would represent that of the general population of the same age.

All 4339 children (2157 males and 2182 females) from a primary school located in the central area of Taipei, the capital city of Taiwan, were examined. Their ages ranged from 7 to 13 . Buccal smears were taken from each child, and were stained by lacto-acetoorcein (Sanderson and Stewart, 1961). One hundred 'suitable nuclei' (Maclean, 1966) of each smear were analysed and only those cells with marginal chromatin bodies on the nuclear membrane were regarded as sex chromatin positive cells. The number of cells with chromatin bodies on each smear was expressed as the percentage of chromatin positive cells.

\section{Results}

Males. Five of 2157 boys were chromatin positive $(2 \cdot 3 / 1000)$. They all had cells containing single sex chromatin bodies. Chromosome studies

\footnotetext{
Received 4 April 1972.

- Cytogenetics Laboratory, Department of Neurology and Psychiatry, National Taiwan University Hospital, Taipei, Taiwan; currently Department of Psychiatry, Washington University School of Medicine, St Louis, Missouri. Supported in part by USPHS grants $\mathrm{MH} 13002$ and $\mathrm{MH} 18864$.

† Cytogenics Laboratory, Department of Neurology and Psychiatry, National Taiwan University Hospital, Taipei, Taiwan.

Reprint requests to M.-T., Department of Psychiatry, Washington University School of Medicine, 4940 Audubon Avenue, St Louis, Missouri 63110, USA.
}

of peripheral blood lymphocytes by a modification of the technique of Moorhead et al (1960) were? done on these 5 boys. Three boys whose per- $\overrightarrow{\vec{\omega}}$ centage of chromatin positive cells were $1 \%(2 \%$ on repeat), $1 \%(3 \%)$, and $1 \%(1 \%)$ had, however, a normal chromosome constitution of 46,XY. Two boys whose percentages were $23 \%(18 \%)$ and $20 \% \dot{\omega}$ $(22 \%)$ showed an abnormal constitution of $47, \mathrm{XXY}$. त्. Thus, 0.9 per $1000(2 / 2157)$ boys were shown to have sex chromosome abnormalities.

Females. Out of the total 2182 girls, one had $\vec{P}$ two chromatin bodies $(0.5 / 1000)$. Her chromo- $\mathbb{D}$ some constitution was $47, \mathrm{XXX}$. All except this $\underset{\mathbb{D}}{\stackrel{\circ}{ }}$ girl had single sex chromatin bodies. No abnormalities in size and shape of chromatin bodies were $\mathbb{\Phi}$ detected. The percentage of chromatin positive $\vec{\varphi}$ cells ranged widely from 2 to $64 \%$ with a mean of 18.20 and SD of 6.32. Chromosome studies those 10 girls whose percentage of chromatin pos tive cells were less than $6 \%$ showed all of them had? normal chromosome constitution of $46, \mathrm{XX}$.

Some details of those 3 children ( 2 boys and 1 girl) with abnormal sex chromosomes are summarized in the following tables (Tables I and Table II).

\section{Discussion}

Males. The present study showed that $2 \cdot 3$ per $1000(5 / 2157)$ boys were chromatin positive. How-

TABLE I

SEX CHROMATIN AND CHROMOSOME ANALYSIS

\begin{tabular}{|c|c|c|c|}
\hline & Case 1 & Case 2 & Case 3 \\
\hline Phenotypic sex & Male & Male & Female \\
\hline $\begin{array}{l}\text { Chromatin bodies (buccal mucosa) } \\
\% \text { of cells with } 0 \\
1 \\
2\end{array}$ & $\begin{array}{r}80 \\
20 \\
0\end{array}$ & $\begin{array}{r}77 \\
23 \\
0\end{array}$ & $\begin{array}{l}42 \\
18 \\
40\end{array}$ \\
\hline $\begin{array}{c}\text { Chromosomes (peripheral blood) } \\
\text { Count distribution }-44 \\
45 \\
46 \\
47 \\
+47 \\
\end{array}$ & $\begin{array}{r}0 \\
0 \\
1 \\
40 \\
0\end{array}$ & $\begin{array}{r}2 \\
3 \\
1 \\
40 \\
0\end{array}$ & $\begin{array}{r}1 \\
2 \\
6 \\
39 \\
0\end{array}$ \\
\hline Karyotype & $47, X X Y$ & $47, \mathrm{XXY}$ & $47, \times \times X$ \\
\hline
\end{tabular}


TABLE II

CLINICAL, PSYCHOLOGICAL, AND FAMILY DATA

\begin{tabular}{|c|c|c|c|}
\hline & Case 1 & Case 2 & Case 3 \\
\hline & Male $(\mathrm{XXY})$ & Male (XXY) & Female (XXX) \\
\hline Date of birth & 25.8 .1962 & 19.11 .1959 & 10.8 .1957 \\
\hline Delivery & Normal, spontaneous & $\begin{array}{l}1 \text { mth premature, oxytocin } \\
\text { induction }\end{array}$ & Normal, spontaneous \\
\hline Birth weight (g) & 3000 & 2200 & 3200 \\
\hline Birth order & $2 / 5$ & $1 / 4$ & $11 / 11$ \\
\hline $\begin{array}{l}\text { Parental ages (yr) at birth } \\
\text { Father } \\
\text { Mother }\end{array}$ & $\begin{array}{l}26 \\
23 \\
\end{array}$ & $\begin{array}{l}29 \\
28 \\
\end{array}$ & $\begin{array}{l}52 \\
44 \\
\end{array}$ \\
\hline $\begin{array}{l}\text { Development } \\
\text { Physical } \\
\text { Mental }\end{array}$ & $\begin{array}{l}\text { Normal } \\
\text { Retarded; speech began at } 5 \text {, } \\
\text { became intelligible at } 6 \text {; quiet } \\
\text { and passive }\end{array}$ & $\begin{array}{l}\text { Slow and sickly } \\
\text { Below average; speech began } \\
\text { at } 1 \frac{1}{2} \text {; shy, obedient, and } \\
\text { inactive }\end{array}$ & $\begin{array}{l}\text { Normal; menarche at } 13 \text {, light and } \\
\text { irregular; secondary sexual } \\
\text { characteristics ( }+ \text { ) } \\
\text { Retarded; very slow in learning to } \\
\text { speak; passive and isolated; very } \\
\text { rarely shows any temper }\end{array}$ \\
\hline Family history & Nothing noteworthy & Nothing noteworthy & $\begin{array}{l}\text { 2nd sib, epileptic; } 5 \text { th sib, died of } \\
\text { unknown causes } 10 \text { days after } \\
\text { birth; mother, } 2 \text { abortions: } 1 \\
\text { between } 9 \text { th and } 10 \text { th, } 1 \text { just } \\
\text { preceding the subject }\end{array}$ \\
\hline Age on examination (yr) & $8 \div \frac{0}{2}$ & $12 \frac{6}{12}$ & $13 \frac{10}{12}$ \\
\hline $\begin{array}{l}\text { Physical } \\
\text { Stigmata } \\
\text { Body weight }(\mathrm{kg}) \\
\text { Body height }(\mathrm{cm}) \\
\text { Head girth }(\mathrm{cm})\end{array}$ & $\begin{array}{l}\overline{26} \cdot 5 \\
133 \\
50 \cdot 0\end{array}$ & $\begin{array}{l}\overline{24 \cdot 0} \\
134 \\
49 \cdot 5\end{array}$ & $\begin{array}{l}\overline{42} \cdot 0 \\
161 \\
55 \cdot 0\end{array}$ \\
\hline Mental state & Silent; no answers to questions & Shy, passive, and obedient & $\begin{array}{l}\text { Quiet; smiles rather than replying to } \\
\text { questions }\end{array}$ \\
\hline $\begin{array}{l}\text { IQ (WISC) } \\
\text { Verbal IQ } \\
\text { Performance IQ } \\
\end{array}$ & $\begin{array}{l}69 \cdot 5 \\
63 \\
76 \\
\end{array}$ & $\begin{array}{l}89 \cdot 5 \\
90 \\
89 \\
\end{array}$ & $\begin{array}{l}71 \cdot 0 \\
61 \\
81\end{array}$ \\
\hline Rorschach test & $\begin{array}{l}\text { Preoccupied with the theme of } \\
\text { death and destructiveness; } \\
\text { inaccurate perception; loose } \\
\text { association process in thinking }\end{array}$ & No significant abnormalities & $\begin{array}{l}\text { Inaccurate perception; stereotyped } \\
\text { thinking; limited interest }\end{array}$ \\
\hline
\end{tabular}

ever, out of the total 5 chromatin positive boys, 3 with very low percentage of chromatin positive cells ranging from $1-3 \%$ were shown to have a normal chromosome constitution in the peripheral blood lymphocytes. There is a possibility that these 3 might be mosaics. Unless chromosome studies of tissues other than peripheral blood can be performed, the possibility of mosaicism cannot be ruled out. When the present study was done, facilities for examining chromosomes of fibroblasts were not available in this laboratory.

In their original study of smears from the oral mucosa of 140 persons ( 81 males and 59 females), Moore and Barr (1955) report that the characteristic female sex chromatin is not found in males. Maclean, Harnden, and Court Brown (1961) state that sex chromatin bodies 'are never found in normal males' in their study of 3000 male and 3000 female newborn babies. If the same criterion is applied to the present study, the figure of $2 \cdot 3 / 1000$ is very close to those reported by various other authors (Table III).

Those sex chromatin bodies found in males with very low percentages of chromatin positive cells may be nonspecific chromocentres arising from any chromosomes and partial products of artefacts of fixation (Moore and Barr, 1954; Barr, 1966). If this view is taken and the 3 boys with $1-3 \%$ of chromatin positive cells are excluded, the frequency of 0.9 per $1000(2 / 2157)$ of the present study is the same as $0.9(5 / 5314)$ found by $N$. Maclean who studied children attending school for the first time at 5 years of age during the years 1963-64 and 1964-65 (Court Brown, 1969). Other figures which are close to these are $0 \cdot 7$ (1/1156 liveborn males) from Kaluga (Bochkov et al, 1967) and 0.6 (1/11563 liveborn males) from Basle (Wiesli, 1962).

Females. The frequency of double chromatin 
TABLE III

REPORTS ON MALES FROM OTHER STUDIES

\begin{tabular}{|c|c|c|c|c|}
\hline \multirow{2}{*}{ Study } & \multirow{2}{*}{ Location } & \multirow{2}{*}{ Liveborn Babies } & \multicolumn{2}{|c|}{ Chromatin (t) } \\
\hline & & & No. & Per 1000 \\
\hline \multirow{3}{*}{$\begin{array}{l}\text { Bergmann (1961) } \\
\text { Gebala and Zytkiewicz } \\
\text { (1964) } \\
\text { Bochkov et al (1967) } \\
\text { Moore (1959) } \\
\text { Maclean et al (1964) }\end{array}$} & Switzerland & 1890 & 4 & $2 \cdot 1$ \\
\hline & $\begin{array}{l}\text { Poland } \\
\text { USSR } \\
\text { Canada } \\
\text { Scotland }\end{array}$ & $\begin{array}{r}960 \\
2433 \\
1911 \\
10725\end{array}$ & $\begin{array}{r}2 \\
5 \\
5 \\
21\end{array}$ & $\begin{array}{l}2 \cdot 1 \\
2 \cdot 1 \\
2 \cdot 6 \\
2 \cdot 0\end{array}$ \\
\hline & & Other groups & & \\
\hline $\begin{array}{l}\text { Hambert (1966) } \\
\text { Kaplan and Norfleet } \\
\text { (1961) }\end{array}$ & $\begin{array}{l}\text { Sweden } \\
\text { USA }\end{array}$ & $\begin{array}{l}2752 \text { military conscripts } \\
1000 \text { army recruits }\end{array}$ & $\begin{array}{l}6 \\
2\end{array}$ & $\begin{array}{l}2 \cdot 2 \\
2 \cdot 0\end{array}$ \\
\hline $\begin{array}{l}\text { Paulsen et al (1964) } \\
\text { Present study }\end{array}$ & $\begin{array}{l}\text { USA } \\
\text { Taiwan }\end{array}$ & $\begin{array}{l}977 \text { hospital outpatients, all ages } \\
2157 \text { primary school children } 7-13 \text { years }\end{array}$ & $\begin{array}{l}2 \\
5\end{array}$ & $\begin{array}{l}2 \cdot 0 \\
2 \cdot 3\end{array}$ \\
\hline
\end{tabular}

TABLE IV

REPORTS ON FEMALES FROM OTHER STUDIES

\begin{tabular}{|c|c|c|c|c|}
\hline \multirow{2}{*}{ Study } & \multirow{2}{*}{ Location } & \multirow{2}{*}{ Populations } & \multicolumn{2}{|c|}{ Chromatin $(++)$} \\
\hline & & & No. & Per 1000 \\
\hline $\begin{array}{l}\text { Marden et al (1964) } \\
\text { Davidenkova et al (1966) } \\
\text { N. Maclean (unpublished } \\
\text { data, see Court Brown, } \\
\text { 1969) } \\
\text { Baikie } \text { et al (1966) } \\
\text { Present study }\end{array}$ & $\begin{array}{l}\text { USA } \\
\text { USSR } \\
\text { Scotland } \\
\text { Australia } \\
\text { Taiwan }\end{array}$ & $\begin{array}{l}2206 \text { liveborns } \\
2458 \text { liveborns } \\
5178 \text { school girls } 5-6 \text { years } \\
3765 \text { female admissions to a general hospital } \\
2182 \text { primary school children } 7-13 \text { years }\end{array}$ & $\begin{array}{l}1 \\
1 \\
5\end{array}$ & $\begin{array}{l}0.5 \\
0.4 \\
0.8 \\
\\
0.8 \\
0.5\end{array}$ \\
\hline
\end{tabular}

bodies was shown to be 0.5 per $1000(1 / 2182)$. Table IV shows that similar figures are reported by others from Madison (Marden, Smith, and McDonald, 1964) and Leningrad (Davidenkova, Ponomarenko, and Verlinskaiia, 1966). Although the figure of the present study is lower than 0.8 reported from Edinburgh (Court Brown, 1969) and Melbourne (Baikie et al, 1966), it is not statistically different from them.

No girls were chromatin negative because of their considerable rarity and probable high infantile mortality rate (Court Brown, 1969). No mosaics were found even among those girls with lower percentage of chromatin positive cells. As mentioned above, chromosome studies of tissues other than the peripheral blood are needed.

The percentage of chromatin positive cells in the present study were very low with a mean of $18.20 \pm$ 6.32 and a wide range of $2-64 \%$. In their original study of buccal smears, Moore and Barr (1955) report that $40-60 \%$ of cells have chromatin bodies at the periphery of nuclei. Maclean (1966) indicates that the variation of the percentages in different studies may be due to the selection of cells and therefore each laboratory must establish its own standards.

In addition to methodological factors, ethnic or geographical variations might, in the authors opinion, influence the percentage of chromatin positive cells in females. In previous studies from Taiwan the mean percentage has varied from $12.7 \%$ in normal newborns (Lai, 1968), 13.4\% in schizophrenics (Tsuang, 1972), to $24.9 \%$ in normals (Huang and Yang, 1964).

The two XXY boys and the XXX girl found in the present study showed no obvious physical abnormalities. The girl had a normal physical development with secondary sexual characteristics. She was mentally retarded with a relatively low verbal IQ, and appeared isolated with stereotyped thinking and inaccurate perception. The 2 boys were shy, quiet, and passive. One was mentally below average and the other was retarded with inaccurate perception and loose association of thinking. On the whole, these findings are compatible with those described by others (Court Brown, 1969; Kidd, Knox, and Month, 1963; Nielsen, 1969). It will be worthwhile following them up after puberty when further physical and mental changes, if any, will become obvious.

\section{Summary}

Buccal smears were examined of all 4339 children 
(ages 7-13) from a primary school in Taiwan. Five of 2157 boys $(2 \cdot 3 / 1000)$ were sex chromatin positive. Chromosome studies of the peripheral blood lymphocytes were done in these 5 boys. Two $(0 \cdot 9 / 1000)$ were $47, \mathrm{XXY}$. Three whose percentages of chromatin positive cells were very low (1$3 \%$ ) had a normal chromosome constitution. Unless chromosome analyses of tissues other than peripheral blood are done, a possibility of mosaicism cannot be ruled out. One of 2182 girls $(0 \cdot 5 / 1000)$ had double sex chromatin bodies and her chromosome constitution was $47, \mathrm{XXX}$. No other chromosome abnormalities were found. The data were comparable with those reported by others. The mean percentages of chromatin positive cells in females were found to be very low $(18 \cdot 20 \pm 6 \cdot 32)$. Aside from various factors influencing the percentages of chromatin positive cells, there might be ethnic or geographical variations. Some clinical and laboratory data of the two XXY and one XXX found in the study were presented. They are compatible with those reported by others. It is worthwhile following them up after puberty when further physical and mental changes, if any, become obvious.

The authors would like to express their gratitude to Y. J. Wang BSc, W. C. Chi BSc, and Mr C. E. Ko of the Cytogenetics Laboratory (Taipei) for their technical assistance in examining the buccal smears and chromosomes. They would also thank J. L. Shen MD, voluntary research worker of the laboratory, for his help in conducting clinical examination of the 3 cases with chromosome abnormalities; $M$. Y. Wang MSc and $\mathrm{Y}$. H. Ko PhD of this department, who performed psychological examination of the cases; and S. M. Chuang $M D$ of the department of pathology and laboratory of cytogenetics of this hospital for his special help in examining chromosomes of case 1 . The authors would like to thank Mr L. Lin, the principal of Jih-Hsin primary school, and school teachers for their generous help which made the present study possible. Finally, Dr E. Slater, Mr J. Shields, and Dr J. Kahn of the Institute of Psychiatry, University of London and Dr E. Robins, Head of the Department of Psychiatry, Washington University School of Medicine, St Louis kindly read the manuscript; their valuable suggestions are highly appreciated.

\section{REFERENCES}

Baikie, A. G., Garson, O.M., Weste, S. M., and Ferguson, J. M. (1966). Numerical abnormalities of the $X$ chromosome. Frequency among inpatients of a general hospital and in a general population. Lancet, 1, 398-400.

Barr, M. L. (1966). Correlations between sex chromatin patterns and sex chromosome complexes in man. In The Sex Chromatin, pp. 129-161, ed. K. L. Moore. Saunders, Philadelphia.
Bergmann, E. (1961). Geschleschts chromatin Bestimmungen am Neugeborenen. Schweizerische medizinische Wochenschrift, 91, 292-294.

Bochkov, N. P., Bulanov, A. G., Bloshansky, Y. M., Lazareva, T. L., Myasnikova, L. A., Talchak, A. A., and Tzertzvadze, G. G. (1967). Population-geographical study of chromosome diseases in man. I. Spontaneous level of sex chromosome anomalies. Genetica, $5,57-72$.

Court Brown, W. M. (1969). Sex chromosome aneuploidy in man and its frequency, with special reference to mental subnormality and criminal behavior. International Review of Experimental Pathology, 7, 31-97.

Davidenkova, E. F., Ponomarenko, A. M., and Verlinskaiia, D. K. (1966). Diagnostika khromosomnykh bolezeni. Klinicheskaya Meditsina, 44, 11-13.

Gebala, A. and Zytkiewicz, A. (1964). Divergence between phenotype and chromatin sex in newborn infants. Pediatria Polska, 39, 557-563.

Hambert, G. (1966). Males with Positive Sex Chromatin. Akademiförlaget-Gumperts, Göteborg.

Huang, S. W. and Yang, Y. M. (1964). Sex chromatin in Chinese phenotypic male and female. Acta Paediatrica Sinica, 5, 161-170.

Kaplan, N. M. and Norfleet, R. G. (1961). Hypogonadism in young men (with emphasis on Klinefelter's syndrome). Annals of Internal Medicine, 54, 461-481.

Kidd, C., Knox, R. S., and Month, D. I. (1963). A psychiatric investigation of triple-X syndrome females. British fournal of Psychiatry, 109, 90-94.

Lai, M. C. (1968). A Study of Sex Chromatin in Normal Chinese Newborns. Thesis, College of Medicine, National Taiwan University, Taiwan.

Maclean, N. (1966). Sex chromatin surveys of newborn babies. In The Sex Chromatin, pp. 202-210, ed. by K. L. Moore. Saunders, Philadelphia.

Maclean, N., Harnden, D. G., and Court Brown, W. M. (1961). Abnormalities of sex chromosome constitution in newborn babies. Lancet, 2, 406-408.

Maclean, N., Harnden, D. G., Court Brown, W. M., Bond, J., and Mantle, D. J. (1964). Sex chromosome abnormalities in new born babies. Lancet, 1, 286-290.

Marden, P. M., Smith, D. W., and McDonald, M. J. (1964). Congenital anomalies in the newborn including minor variations. fournal of Pediatrics, 64, 354-371.

Moore, K. L. (1959). Sex reversal in newborn babies. Lancet, 1, 217-219.

Moore, K. L. and Barr, M. L. (1954). Nuclear morphology, according to sex in human tissues. Acta Anatomica, 21, 197-208.

Moore, K. L. and Barr, M. L. (1955). Smears from the oral muccosa in the detection of chromosomal sex. Lancet, 2, 57-58.

Moorhead, P. S., Nowell, P. C., Mellman, W. J., Battips, D. M., and Hungerford, D. A. (1960). Chromosome preparations of leukocytes cultured from human peripheral blood. Experimental Cell Research, 20, 613-616.

Nielsen, J. (1969). Klinefelter's syndrome and the XYY syndrome. A genetical, endocrinological and psychiatric-psychological study of thirty-three severely hypogonadal male patients and two patients with XYY syndrome. Acta Psychiatrica Scandinavica (Suppl.), 209.

Paulsen, C. A., de Souza, A., Yoshizumi, T., and Lewis, B. M. (1964). Results of a buccal smear survey in non-institutionalized adult males. Fournal of Clinical Endocrinology and Metabolism, 24, 1182-1187.

Sanderson, A. R. and Stewart, J. S. S. (1961). Nuclear sexing with aceto-orcein. British Medical fournal, 2, 1065-1067.

Tsuang, M. T. (1972). Psychiatric genetics in Taiwan. International fournal of Mental Health, 1, 221-230.

Wiesli, B. (1962). Vergleich des phenotypischen und zelkernmorphologischen Geschlechlechtes bei 3029 Neugeborenen. Acta Anatomica, 51, 377-383. 